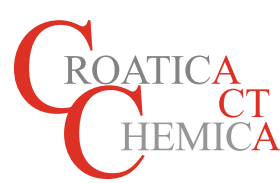

\title{
Reminiscences of Milan Randić
}

\author{
by Roger Mallion \\ Canterbury, England, UK
}

A LTHOUGH I have been involved in Mathematical Chemistry (specifically, Graph Theory) since the late 1960s, and thus have long been well aware of the name of Milan Randić - and having seen him from a distance at some of the early conferences in old Yugoslavia - I did not actually hold a conversation with him until a conference on chemical applications of topology and graph theory, held in the University of Georgia, USA, in 1983. I was, at some stage, in the back seat of a car being driven by a colleague and Milan was in the front passenger seat, looking every inch like the embodiment of an Englishman's stereotypical idea of an elegant, suave and distinguished 'EasternEuropean' scientist. Since then, it has been my privilege to have met him and socialised with him many times in the succeeding nearly forty years - in several places but largely, of course, at conferences in 'the Pearl of the Adriatic' - and it has always been a joy to do so.

If I had to think of one word to describe Milan in a personal capacity it would be 'convivial'. Another adjective that would be appropriate is one that probably doesn't have much meaning outside native speakers of the English language: 'clubbable'. This is a word invented by the $18^{\text {th }}$ century literary giant Dr Johnson to describe a man (and in those days, it was, of course, just men ...) who is '... fond of good talk, good food and good drink'.

Milan must have had some experience of this 'clubbable' sort of society when he was a postgraduate at Cambridge in the 1950s. He was there to do his PhD under Norman Sheppard, FRS. In those days, anyone in Britain who was from Yugoslavia would have been legally classified as 'an alien'. Accordingly, Milan tells how he had to register with the police when he arrived in Cambridge. He tells the story that he presented himself at the local police station and, when he had explained his mission, the desk sergeant asked him what his name was. Milan answered 'Milan Randić'. With a frown, the sergeant gave him a piece of paper and a pencil and said: 'Write it down'. So, Milan wrote 'MILAN R A N D I C'. The sergeant looked at the paper, then tore it up into little pieces and threw it into the

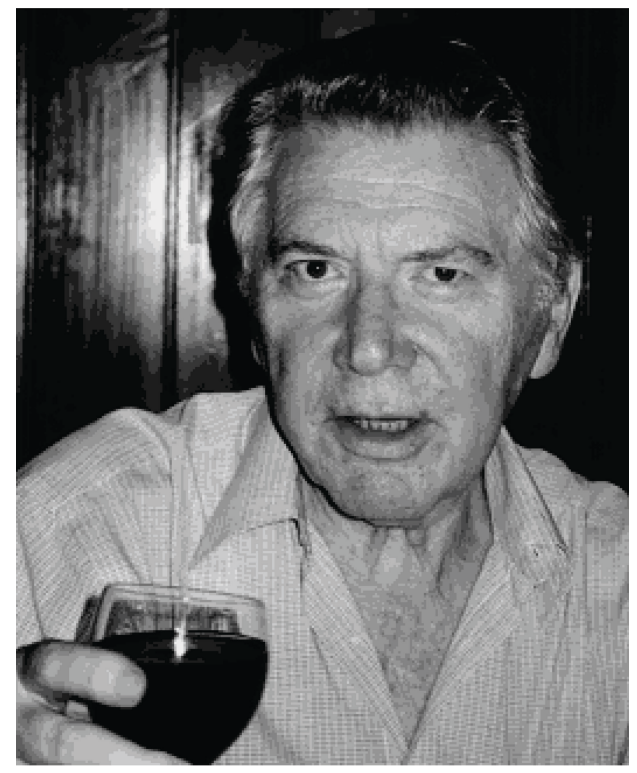

Milan Randić is in full agreement with Plutarch (46-119 A.D.), who characterized wine as, "Of drinks - the most useful; Among medication - the most tasteful; Among food - the most enjoyable." Reprinted with permission from Chem. Rev. 2003, 103, 3449-3605. Copyright (2003) American Chemical Society.

air, saying 'No accents!' To which Milan bravely responded with the correction: 'It is not accent, it is diacritical mark'. The exasperated sergeant then concluded the interview by saying: 'If you can't do it without accents, just put a cross!' (In Britain, in those days, putting a cross was the legal way in which an illiterate person could sign an official document!)

I took every opportunity to interact with Milan, not only because of our shared interest in the magnetic properties of conjugated systems but also because of his invariable sociability and his sheer joie de vivre. We both like to sample the local wines and Milan (as was the case with the aforesaid Dr Johnson) likes to 'fold his legs and have his talk.' One of my favourite recollections of these occasions was at a Dubrovnik meeting where the 
'conference jolly' was a trip by boat, and included lunch on board the vessel whilst it was moored at one of the Adriatic islands. I was sitting opposite Milan and we were both at the end of a rectangular table and it was a privilege to have had his company on such a perfect day under such convivial conditions for so extended a time. It was a delightful experience.

I was not present for the next anecdote. It was told to me by the late Ed Kirby (to whom I had the honour of paying tribute in the proceedings of the 2019 MATH/CHEM/COMP meeting.) The two of them were travelling by a morning train from Zagreb to Ljubljana. Near the beginning of the journey the hospitality trolly came round and Milan bought a couple of cans of beer for the journey. He invited Ed to join him but the latter politely declined on the grounds that it was 'too early'. Milan opened one of the cans, partook of a swig of it, and then, contemplating, admiring and holding up the can, he said to Ed: Ah! Excellent! That really hits the spot. You don't know what you're missing.' The journey then proceeded very convivially and, as the train began to approach Ljubljana, Milan started to clear the detritus of the journey from his table, gathering it ready to put into a litter bin as they left the train. It was then that Milan's visage clouded over, and he looked thunderously at the can, as he began to read that it was inscribed 'Non-Alcoholic Beer'...

My final reminiscence also involves Ed. Kirby. This time it was at a meeting that Damir Vukičević organised in Split in the summer of 2014. This took place at a conference centre in a remote setting, outside the town. The social interacting was done al fresco, under a veranda, and the conference accommodation was in a large building directly opposite. On one occasion the evening wore on and, eventually, the only people left in (very animated) conversation were Milan, Ed Kirby, and me. When at last we collectively decided that it was time for us to retire to bed, we walked the few metres to the front door of the accommodation building only to find, to our horror, that it was locked. We tried it several times, but it wouldn't budge. We had only one option: Ed carefully worked out, from looking at the building from the outside, which window was

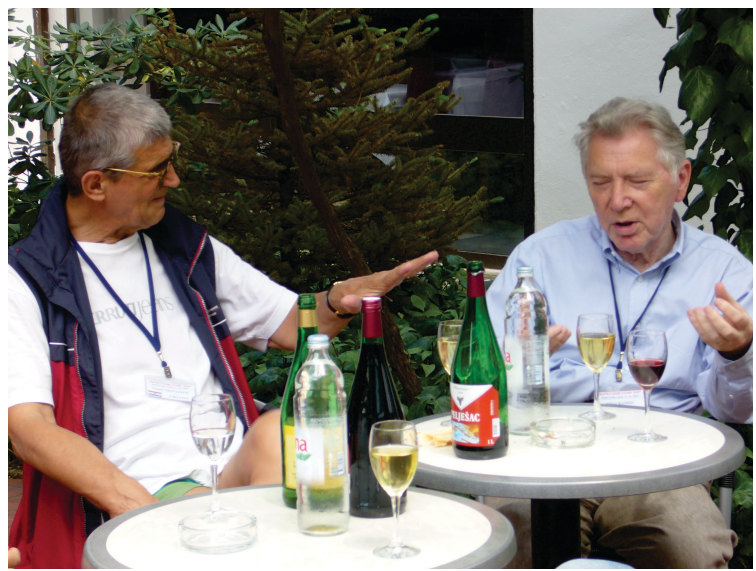

Nenad Trinajstić \& Milan Randić, Math/Chem/Comp, June 2007.

the one to his room (in which Jean Kirby, Ed's wife, had long been ensconced), and we could do nothing other than aim small stones at this window in the hope of arousing Jean. Eventually a puzzled Jean appeared at the window - to our relief, we had identified the correct window - and Jean, our saving angel, came down and duly opened the front door to us, moments later. The next day, we all laughed at the thought of the distinguished and venerable Milan (who, even then, was well over eighty years of age) trying to gain access to his lodgings as a teenager might have done after a wild night out 'on the town'!

My one regret about my association with Milan over nearly a forty-year period is that I never jointly published anything with him. Many times we corresponded about mutual interests, sent each other preprints, and so on (and some of these interactions were acknowledged in published papers). However, my 'Randić Number' remains stubbornly at 2 , rather than being 1 , as I should have very much have liked it to be...

It is a privilege to conclude by wishing Milan a very happy $90^{\text {th }}$ Birthday.

Roger Mallion, Canterbury, England, UK June $9^{\text {th }}, 2021$ 